\title{
Role of Psychiatric Nurse in Palliative Care
}

\author{
Bushra Mushtaq* \\ Psychiatry Nursing Scholar, Skims Nursing College, Srinagar, India
}

Submission: March 15, 2018; Published: March 26, 2018

*Corresponding author: Bushra Mushtaq Msc, Psychiatry Nursing Scholar, Skims Nursing College, Srinagar, Kashmir, India, Email: bushra.mushtaq77@gmail.com

\begin{abstract}
There is an increase in the life threatening disease and their by increasing the mortality rates associated with these diseases. More over there is always a risk of developing a psychiatric problem in the clients having fatal diseases. Psychiatric nurse has a role to play for alleviating the mental suffering faced by these clients and helping them to live a life with minimum sufferings and decreased mental problems. Palliative care is a broad term which includes the special care for the seriously ill clients, also including their family members in the care. The care focuses on relieving signs and symptoms related to the serious illness. The care included increases the quality of the life. As there are presently different serious illnesses with drastic outcomes. These illnesses not only effect the physiology of a person but also the psychological well being of that person.
\end{abstract}

\section{Introduction}

Health is holistic in nature which covers all dimensions; physical, psychological, social, spiritual dimension, if any one of the dimension is altered the others get automatically affected. If there is any physiological crisis, the psychological well being of a person gets targeted. Here comes the role of a psychiatric nurse and she has to take care of different aspects like improving the quality of life, Effective communication, Involvement of family members, Reporting to psychiatrist. Psychiatric nurse has a role to play in both home care palliative program as well as in general hospitals. Psychiatric nurse can craft interventions to reduce clients anxiety, promote physical and psychological comfort and well-being. Various serious illnesses can lead to psychiatric problems like stress, anxiety, depression which can lead to suicides and which reduce the quality of life [1]. Psychiatric nurse can help in reduction of mental stresses which in turn can help in over all the well being of the individual, Following are some aspects on which psychiatric nurse can work on :

a. Assessment: Psychiatric nurse can perform the full assessment of the client besides the general nursing assessment performed by assigned nurse, gathers the comprehensive data related to health that is pertinent to the clients present health situation. The information database is gathered from variety of sources: from client, family, consultation with the other health care team. Close observation of the client and his environment is carried out. A special tool know as Bio-psychosocial assessment tool can be used and a brief Mental Status Examination can be carried out, which can act as the guide about the mental functioning of the client.

b. Satisfying Nurse-Client Relationship: As the client who has any physiological alignments finds very much difficultly in developing the effective relationship with the client. Psychiatric nurse uses the effective skill of establishing a good relationship with the client which will help the client in building trust with the nurse. Developing a satisfying elation ship can help the client to catharsis his the feelings, ventilate the thoughts, clarify the confusions related to the disease condition.

c. Effective Communication: Psychiatric nurse uses the effective means to communicate with the client which helps in developing the good rapport. Communication by psychiatric nurse can be carried out in the form of process recording which can help in getting the mental processes going out in the mind of the client.

d. Psychological Support: Being with the disease the clients are always mentally tensed and pre occupied with the disease condition, Psychiatric nurse can provide the psychological support in dealing with disease condition and by which the client can find the effective ways to feel psychologically healthy.

e. Diversion Techniques: Psychiatric nurse can use the diversion techniques when the client feels any physiological symptom like pain. Diversion technique can change the mood 
of the client, it interrupts the client from negative mood and distracts him by engaging him in different activity. The different ways of distraction are music, watching television, reading, talking to family and friends etc.

f. Stress Management: Various adaptive coping strategies can be taught to client by a psychiatric nurse, like problem solving technique in which the psychiatric nurse helps the client to view the problem or situation objectively and to seek assistance to accomplish and solving the problem. Other ways to manage stress which can be taught are: relaxation, meditation, having pets etc.

\section{References}

1. Mary C Townsend (2015) Psychiatric mental health nursing: concepts of care in Evidence based Practice. ( $8^{\text {th }}$ edn), FA Davis Company, USA.

\section{Your next submission with Juniper Publishers will reach you the below assets}

- Quality Editorial service

- Swift Peer Review

- Reprints availability

- E-prints Service

- Manuscript Podcast for convenient understanding

- Global attainment for your research

- Manuscript accessibility in different formats

( Pdf, E-pub, Full Text, Audio)

- Unceasing customer service

Track the below URL for one-step submission https://juniperpublishers.com/online-submission.php 